\title{
Pengaruh Komposisi Media Tanam dan Plant Growth Promoting Rhizobacteria terhadap Pertumbuhan Benih Pepaya di Pembibitan dan di Lapangan
}

\section{Effect of growing media and plant growth promoting rhizobacteria (PGPR) on the growth of papaya seeds in the nursery and field}

\author{
Winarso D. Widodo ${ }^{*}$, Ketty Suketi dan Septy Yurihastuti \\ Departemen Agronomi dan Hortikultura, Fakultas Pertanian, Institut Pertanian Bogor \\ [Bogor Agricultural University], Jalan Meranti, Kampus IPB Dramaga, Bogor 16680, Indonesia \\ Telp. \& Faks. 0251-8629353 e-mail: agronipb@indo.net.id \\ *Penulis untuk korespondensi : wd_widodo@yahoo.com
}

Disetujui 14 Mei 2018 / Published online 21 Mei 2018

\begin{abstract}
Papaya (Carica papaya L.) is one of tropical fruits that have been cultivated intensively in Indonesia. The objective of this research is to determine the effect of growing media and PGPR on growth of papaya plants in the nursery and in the field. The experiment was conducted from July to December 2016 in Mekarsari field, Rancabungur District, Bogor Regency, with randomized completely block design (RCBD) with two factors and three replications. The treatments was consisted of PGPR suspension with concentration of 0, 5, 10 and $15 \mathrm{ml} / \mathrm{l}$ and growing media composition was consisted of control of soil and manure (MO), soil, manure and husk (M1), and soil, manure and cocopeat (M2) so there were 12 combinations of treatments. The results of this experiment in the nursery showed that concentration of PGPR suspension affect on plant height, stem diameter and leaf length, while in the field showed that concentration of PGPR suspension affect on plant height, number of leaves, leaf length, and leaf width, but did not affect on stem diameter of papaya plants. Composition of growing media during in the nursery did not affect to all parameters. Meanwhile, during the observations in the field, media composition of soil and manure (MO) and soil, manure and husk (M1) was able to affect on plant height and number of leaves.
\end{abstract}

Keywords : biological agents, Carica papaya L., media composition

\begin{abstract}
ABSTRAK
Pepaya (Carica papaya L.) merupakan salah satu buah tropika yang telah dibudidayakan secara intensif di Indonesia. Penelitian ini bertujuan untuk mengetahui pengaruh komposisi media tanam dan konsentrasi PGPR yang tepat untuk pertumbuhan bibit pepaya di pembibitan dan di lapangan. Percobaan di laksanakan pada bulan Juli hingga Desember 2016 di Kebun Mekarsari, Kecamatan Rancabungur, Kabupaten Bogor, dengan rancangan kelompok lengkap teracak (RKLT) 2 faktor dan 3 ulangan. Perlakuan terdiri atas suspensi PGPR dengan konsentrasi 0, 5, 10 dan 15 dan komposisi media tanam yang terdiri atas kontrol tanah: pupuk kandang (M0), tanah: pupuk kandang: sekam (M1), dan tanah: pupuk kandang: cocopeat (M2) sehingga terdapat 12 kombinasi perlakuan. Hasil percobaan di pembibitan menunjukkan bahwa konsentrasi suspensi PGPR mempengaruhi tinggi tanaman, diameter batang dan panjang daun, sedangkan di lapangan menunjukkan bahwa konsentrasi suspensi PGPR mempengaruhi tinggi tanaman, jumlah daun, panjang daun dan lebar daun, tetapi tidak mempengaruhi terhadap diameter batang tanaman pepaya. Komposisi media tanam selama di pembibitan tidak mempengaruhi semua parameter. Sedangkan selama pengamatan di lapangan, komposisi media tanah dan pupuk kandang (M0) dan tanah, pupuk kandang dan sekam (M1) mampu mempengaruhi tinggi tanaman dan jumlah daun.
\end{abstract}

Kata kunci : agen hayati, Carica papaya L., komposisi media 


\section{PENDAHULUAN}

Pepaya (Carica papaya L.) merupakan salah satu buah tropika yang telah dibudidayakan secara intensif di Indonesia. Tanaman pepaya dapat tumbuh pada bermacam-macam tipe tanah dengan drainase yang baik, apabila drainase buruk maka dapat terjadi pembusukan pada akar (Nakasone dan Paull, 1998). Buah ini memiliki nilai nutrisi yang baik dan dapat dikonsumsi baik sebagai buah segar maupun produk olahan. Menurut Sujiprihati dan Suketi (2009) buah pepaya kaya akan karbohidrat, karoten, riboflavin, dan vitamin C. Buah muda, daun dan bunga pepaya dapat digunakan sebagai sayuran. Daun tanaman pepaya berkhasiat sebagai obat malaria, kejang perut, sakit panas, dan dapat menyembuhkan penyakit beri-beri. Banyaknya manfaat yang dapat diberikan, maka pepaya merupakan salah satu buah yang diminati penduduk Indonesia.

Menurut Suketi et al. (2010) kandungan zat gizi pepaya IPB yaitu $86,48 \%$ air, $0,27 \%$ abu, $0,010 \%$ lemak, $4,13 \%$ protein, $0,006 \%$ fosfor, 1,35\% kalium, $68 \mathrm{mg}$ kalsium, 282,00 ppm Fe dan vitamin C 105,09-154,89/100 g. Dari sisi pengobatan menurut Sobir (2009), akar pepaya biasa digunakan untuk menyembuhkan sakit ginjal dan kandung kemih. Daunnya bermanfaat untuk menyembuhkan penyakit malaria, kejang perut, dan sakit panas. Selain itu daun pepaya bermanfaat untuk menambah nafsu makan dan menyembuhkan penyakit beri - beri. Daun pepaya juga dapat digunakan untuk ransum ayam.

Chaerningrum (2010) menyatakan bahwa tipe pepaya yang banyak dibudidayakan oleh petani di daerah Bogor adalah tipe Bangkok dan California. Keduanya merupakan tipe pepaya yang paling banyak diminati oleh konsumen. BPTBT (2008) juga menyatakan pepaya tergolong tanaman yang memerlukan cahaya penuh. Tanaman pepaya yang mendapatkan sinar matahari dalam jumlah banyak akan lebih banyak berbunga dan berbuah, mempercepat proses pemasakan buah dan mempengaruhi kemanisan buah. Menurut PKHT (2009) tipe California merupakan tipe pepaya berumur genjah, termasuk dalam buah ukuran sedang dengan berat rata-rata $1,2 \mathrm{~kg}$, memiliki bentuk buah silindris, dan daging buah yang tebal. Tanaman hortikultura sangat sesuai dikembangkan dan diusahakan pada kondisi kepemilikan lahan yang terbatas seperti di Indonesia yang sebagian besar lahan pertaniannya digunakan untuk lahan perkebunan. Menurut Beets (1982) dibutuhkan teknik budidaya pertanian yang mampu meningkatkan efisiensi penggunaan lahan.
Produksi pepaya di Indonesia mengalami fluktuasi dari tahun 2010 - 2014. Produksi pepaya pada tahun 2010 mengalami penurunan sebesar 97.043 ton, produksi meningkat pada tahun 2011 sebesar 958.251 ton. Namun sampai tahun 2014 terjadi penurunan produksi sebesar 118.132 ton (BPS, 2015). Mengacu pada Suyanti (2011) sentra produksi utama buah pepaya adalah Jawa Timur (Kediri, Malang dan Tulungagung), Jawa Tengah (Klaten dan Boyolali), Jawa Barat (Bogor, Sukabumi dan Garut), Sumatera Utara (Deli Serdang), Kalimantan Barat (Pontianak), dan Kalimantan Timur (Samarinda dan Balikpapan).

Keberhasilan budidaya pepaya diawali dengan penggunaan bibit yang berkualitas sehingga dapat menghasilkan buah yang bermutu. Penanaman benih dapat dilakukan dengan dua cara, yaitu penanaman benih langsung di lahan dan penanaman benih yang disemai terlebih dahulu di persemaian yang disebut dengan pembibitan (Kalie, 1999). Media tanam yang baik untuk pertumbuhan bibit juga haruslah memiliki sifat fisik seperti mampu mengalirkan kelebihan air yang tidak dibutuhkan dengan aerasi dan drainase yang baik, tidak mengandung bahan kimia yang beracun, tingkat kemasaman sesuai dengan toleransi tanaman, tidak mengandung hama dan penyakit serta memiliki daya pegang air yang cukup (Azhari, 2006). Media tanam juga harus mengandung satu atau lebih usur esensial untuk pertumbuhan tanaman dan unsur esensial tersebut berada dalam bentuk yang dapat diserap tanaman (Harjadi, 1989). Menurut Utami et al. (2013) terdapat dua komposisi media tanam yang dapat mempengaruhi tinggi tanaman, jumlah daun, diameter batang dan waktu bunga pertama muncul di lapangan. Komposisi media tanam yang pertama dengan menggunakan tanah, pupuk kandang dan sekam. Komposisi media tanam yang kedua dengan menggunakan tanah, pupuk kandang dan cocopeat. Nugrahani (2015) juga menyatakan bahwa media tanam yang paling ekonomis adalah campuran media tanam berupa tanah, pupuk kandang, dan arang sekam dengan perbandingan $(1: 1: 2)$.

Pertumbuhan bibit pepaya yang meningkat selain dengan cara media tanam adalah dengan menggunakan PGPR (plant growth promoting rhizobacteria) atau rhizobakteri. PGPR adalah sejenis bakteri yang hidup di sekitar perakaran tanaman, hidupnya secara berkoloni menyelimuti akar tanaman pada lapisan tanah tipis antara 1 hingga $2 \mathrm{~mm}$ di sekitar zona perakaran. Menurut Tanuta (2006) PGPR juga mampu menyediakan hara dengan menambahkan $\mathrm{N} 2$ dari udara secara asimbiosis dan melarutkan 
hara $\mathrm{P}$ yang terikat di dalam tanah, dan PGPR dapat mengendalikan patogen yang berasal dari tanah dengan cara menghasilkan berbagai senyawa atau metabolit anti patogen seperti siderophore, $\beta$ 1,3 glukanase kitinase, antibiotik, dan sianida. Menurut Nasib (2015) konsentrasi larutan PGPR $5 \mathrm{ml} / \mathrm{l}$ dan lama perendaman PGPR selama 30 menit pada pertumbuhan bibit pepaya memberikan respon yang positif terhadap diameter batang atau jumlah daun pepaya di pembibitan. Perlakuan PGPR merupakan alternatif yang cukup baik untuk digunakan dalam perlindungan tanaman karena PGPR dapat diaplikasikan ke benih atau dicampurkan ke dalam tanah untuk pembibitan atau saat pindah tanam. Penelitian ini bertujuan untuk mengetahui komposisi media tanam dan konsentrasi PGPR yang tepat untuk pertumbuhan bibit atau tanaman pepaya di lapangan.

\section{BAHAN DAN METODE}

Percobaan dilaksanakan di Kebun Mekarsari, Kecamatan Rancabungir, Kabupaten Bogor, pada bulan Juli hingga Desember 2016. Bahan yang digunakan adalah benih pepaya Callina, pupuk hayati PGPR dengan kandungan rhizobakteria Bacillus polymyxa dan Pseudomonas fluorescens yang diperoleh dari Departemen Proteksi Tanaman, Institut Pertanian Bogor. Media tanaman yang digunakan yaitu tanah, pupuk kandang, cocopeat, dan arang sekam. Alat-alat yang digunakan antara lain tray semai, polybag ukuran $10 \mathrm{~cm} \times 15 \mathrm{~cm}$, ember, cangkul, kored, gelas ukur, wadah, meteran, penggaris, jangka sorong digital, label, alat tulis, timbangan digital, hand sprayer, dan alat-alat pertanian

Percobaan dilakukan menggunakan rancangan faktorial dengan dua faktor disusun dalam Rancangan Kelompok Lengkap Teracak (RKLT). Faktor pertama adalah konsentrasi suspensi PGPR yaitu $0 \mathrm{ml} / \mathrm{l}$ tanpa direndam (K0), $5 \mathrm{ml} / \mathrm{l} 60$ menit (K1), $10 \mathrm{ml} / \mathrm{l} 60$ menit (K2), dan $15 \mathrm{ml} / \mathrm{l} 60$ menit (K3). Faktor kedua adalah media tanam yang digunakan yaitu sebagai kontrol tanah: pupuk kandang (M0), tanah: pupuk kandang: sekam (M1), tanah: pupuk kandang: cocopeat (M2). Percobaan terdiri atas 12 perlakuan dengan 3 ulangan sehingga terdapat 36 satuan percobaan. Setiap satuan percobaan terdiri atas 5 bibit pepaya sehingga jumlah tanaman yang digunakan 180 tanaman. Pengamatan dilakukan pada 3 contoh bibit sehingga jumlah yang diamati sebanyak 108 tanaman.

Benih disemai dalam tray semai yang telah diisi dengan media tanam campuran tanah dan kompos dan siap dipindah tanam ke polybag setelah bibit sebagian besar telah tumbuh seragam. Pengamatan yang dilakukan saat di pembibitan adalah waktu berkecambah, tinggi tanaman, jumlah daun, diameter batang. Setelah berumur empat minggu di tanam dalam polybag, bibit kemudian di pindah tanamkan di lapangan. Pengamatan yang di lakukan di lapangan adalah pengukuran tinggi tanaman, jumlah daun, diameter batang, panjang daun, lebar daun, waktu awal berbunga, dan jumlah bunga yang tumbuh. Semua data yang terkumpul kemudian dilakukan analisis data menggunakan analisis sidik ragam (Uji F) pada taraf 5\%. Jika hasil Uji F berpengaruh nyata, akan dilakukan uji lanjut menggunakan Uji Selang Berganda Duncan (DMRT) dengan taraf 5\%.

\section{HASIL DAN PEMBAHASAN}

\section{Pertumbuhan Bibit Pepaya di Polybag}

Hasil analisis sidik ragam menyimpulkan bahwa pertumbuhan bibit pepaya callina di polybag (Tabel 1) perlakuan PGPR hanya berpengaruh terhadap tinggi tanaman, diameter batang dan panjang daun, tetapi tidak berpengaruh terhadap jumlah daun dan lebar daun. PGPR mempengaruhi tinggi tanaman dan diameter batang pepaya di polybag dari minggu ke 1 hingga minggu ke 4 setelah tanam. Sedangkan pada peubah panjang daun tanaman pepaya hanya berpengarruh pada minggu ke 1 saja. Berbeda dengan perlakuan PGPR, perlakuan media tanam pada tanaman pepaya di polybag tidak berpengaruh terhadap semua peubah.

Minggu ke-1 pada interaksi konsentrasi suspensi PGPR dan media tanam merupakan minggu terbaik karena mampu berpengaruh meningkatkan tinggi tanaman yaitu sebesar 3,83 $\mathrm{cm}$ yang berbeda dengan perlakuan lainnya seperti pada Tabel 1 . 
Tabel 1. Hasil analisis sidik ragam pengaruh perlakuan terhadap pertumbuhan bibit pepaya di polybag

\begin{tabular}{|c|c|c|c|c|c|}
\hline Peubah & Waktu (MST) & $\begin{array}{l}\text { Perlakuan PGPR (F- } \\
\text { hitung) }\end{array}$ & $\begin{array}{c}\text { Perlakuan } \\
\text { Media Tanam } \\
\text { (F-hitung) }\end{array}$ & Interaksi (KxM) & $\mathrm{KK}(\%)$ \\
\hline \multirow[t]{4}{*}{ Tinggi tanaman } & 1 & $11,12 * *$ & $1,99 \mathrm{tn}$ & $3,83 * *$ & 9,78 \\
\hline & 2 & $4,28 *$ & $2,92 \mathrm{tn}$ & $1,58 \mathrm{tn}$ & 11,98 \\
\hline & 3 & $4,26^{*}$ & $2,75 \mathrm{tn}$ & $1,57 \mathrm{tn}$ & 13,04 \\
\hline & 4 & $5,14 * *$ & $2,91 \mathrm{tn}$ & $1,48 \mathrm{tn}$ & 12,45 \\
\hline \multirow[t]{3}{*}{ Jumlah daun } & 2 & $0,06 \mathrm{tn}$ & $0,49 \mathrm{tn}$ & $0,33 \mathrm{tn}$ & 11,03 \\
\hline & 3 & $0,90 \mathrm{tn}$ & $1,17 \mathrm{tn}$ & $0,50 \mathrm{tn}$ & 6,10 \\
\hline & 4 & $2,34 \mathrm{tn}$ & $0,66 \mathrm{tn}$ & $0,44 \mathrm{tn}$ & 5,57 \\
\hline \multirow[t]{4}{*}{ Diameter batang } & 1 & $26,56 * *$ & $2,31 \mathrm{tn}$ & $0,76 \mathrm{tn}$ & 21,68 \\
\hline & 2 & $38,63 * *$ & $2,07 \mathrm{tn}$ & $1,16 \mathrm{tn}$ & 17,44 \\
\hline & 3 & $18,84 * *$ & $2,50 \mathrm{tn}$ & $0,38 \mathrm{tn}$ & 16,77 \\
\hline & 4 & $4,00 *$ & $2,94 \mathrm{tn}$ & $0,75 \mathrm{tn}$ & 17,63 \\
\hline \multirow[t]{4}{*}{ Panjang daun } & 1 & $3,26^{*}$ & $3,13 \mathrm{tn}$ & $2,05 \mathrm{tn}$ & 13,75 \\
\hline & 2 & $2,22 \mathrm{tn}$ & $1,40 \mathrm{tn}$ & $1,48 \mathrm{tn}$ & 13,53 \\
\hline & 3 & $1,61 \mathrm{tn}$ & $1,15 \mathrm{tn}$ & $1,44 \mathrm{tn}$ & 12,33 \\
\hline & 4 & $2,48 \mathrm{tn}$ & $1,73 \mathrm{tn}$ & $1,96 \mathrm{tn}$ & 11,66 \\
\hline \multirow[t]{4}{*}{ Lebar daun } & 1 & $2,79 \mathrm{tn}$ & $1,43 \mathrm{tn}$ & $1,16 \mathrm{tn}$ & 10,49 \\
\hline & 2 & $2,89 \mathrm{tn}$ & $0,75 \mathrm{tn}$ & $1,53 \mathrm{tn}$ & 11,56 \\
\hline & 3 & $0,98 \mathrm{tn}$ & $1,44 \mathrm{tn}$ & $1,46 \mathrm{tn}$ & 14,70 \\
\hline & 4 & $1,00 \mathrm{tn}$ & $2,00 \mathrm{tn}$ & $1,18 \mathrm{tn}$ & 14,72 \\
\hline
\end{tabular}

Keterangan : MST : Minggu Setelah Tanam, KK : koefisien keragaman, tn : tidak nyata, $*$ : berpengaruh nyata pada taraf 5\%, $* *$ : berpengaruh sangat nyata pada taraf $5 \%$.

Interaksi konsentrasi suspensi PGPR dan media tanam pada tinggi tanaman pepaya di polybag pada minggu ke 1 yang memiliki kombinasi terbaik adalah K3M0 dengan suspensi PGPR $15 \mathrm{ml} / \mathrm{l}$ dan campuran media tanamnya adalah tanah dan pupuk kandang sebesar 7,82 cm, sedangkan nilai interaksi yang paling rendah pada kombinasi konsentrasi suspensi K0M0 yaitu 0 $\mathrm{ml} / \mathrm{l}$ dan campuran media tanamnya adalah tanah dan pupuk kandang sebesar $5,16 \mathrm{~cm}$ seperti pada Tabel 2.

Tabel 2. Interaksi konsentrasi suspensi PGPR dan media tanam terhadap pertumbuhan tanaman pepaya di polybag

\begin{tabular}{|c|c|c|c|c|}
\hline \multirow{2}{*}{ Perlakuan } & \multicolumn{4}{|c|}{ Konsentrasi } \\
\hline & 0 & 5 & 10 & 15 \\
\hline & & .......... & & \\
\hline M0 & 5,16 & 6,37 & 6,34 & 7,82 \\
\hline M1 & 5,80 & 5,65 & 6,32 & 7,81 \\
\hline M2 & 5,49 & 6,30 & 6,38 & 5,75 \\
\hline
\end{tabular}

Keterangan : Angka yang diikuti huruf berbeda pada kolom yang sama menunjukkan berbeda nyata berdasarkan hasil uji lanjut Duncan Multiple Range Test (DMRT) $\alpha=5 \%, 0$ : K0, 5: K1, 10: K2, 15: K3, Tanah: pupuk kandang (M0), tanah: pupuk kandang: sekam (M1), tanah: pupuk kandang: cocopeat (M2).

Pertumbuhan vegetatif bibit pepaya di polybag diukur berdasarkan beberapa variabel yaitu tinggi tanaman, jumlah daun, diameter batang, panjang daun, dan lebar daun. Analisis uji lanjut pertumbuhan bibit pepaya di polybag pada perlakuan PGPR 1 MST (Tabel 3) menyimpulkan bahwa konsentrasi suspensi PGPR $15 \mathrm{ml} / \mathrm{l}$ (K3) berpengaruh terhadap tinggi tanaman $7,12 \mathrm{~cm}$, diameter batang 1,71 $\mathrm{mm}$ dan panjang daun 2,41 $\mathrm{cm}$ yang memiliki nilai paling tinggi, sedangkan untuk konsentrasi suspensi PGPR terendah pada ketiga peubah yaitu konsentrasi $0 \mathrm{ml} / \mathrm{l}$ (K0). Komposisi media tanam pada 1 MST hanya berpengaruh terhadap panjang daun dengan komposisi media tanah dan pupuk kandang (M0) sebesar $2,34 \mathrm{~cm}$.

Tabel 3 menyatakan bahwa konsentrasi suspensi $15 \quad \mathrm{ml} / \mathrm{l} \quad(\mathrm{K} 3)$ menghasilkan tinggi tanaman dan panjang daun paling besar yaitu 12,00 $\mathrm{cm}$ dan $3,93 \mathrm{~cm}$, sedangkan jumlah terkecil diperoleh oleh konsentrasi suspensi $0 \mathrm{ml} / \mathrm{l}$ tanpa direndam (K0) yaitu $9,69 \mathrm{~cm}$ dan $3,41 \mathrm{~cm}$. Hasil penelitian ini berbeda dengan penelitian Nasib (2015) menunjukkan bahwa konsentrasi suspensi $15 \mathrm{ml} / \mathrm{l}$ menghasilkan tinggi tanaman paling rendah yaitu $8,99 \mathrm{~cm}$. Konsentrasi suspensi PGPR pada pertumbuhan bibit pepaya di polybag memberi cukup respon positif. Hal ini diduga 
karena adanya interaksi antara konsentrasi suspensi PGPR dan perendaman pada benih pepaya. Berbeda dengan PGPR hasil komposisi media tanam pada saat penanaman 4 MST di polybag hanya berpengaruh pada peubah diameter batang saja, yaitu dengan nilai tertinggi 3,26 mm dengan komposisi media tanah, pupuk kandang dan sekam (M1) sedangan nilai terendah $2,76 \mathrm{~mm}$ dengan komposisi tanah, pupuk kandang dan cocopeat (M2). Hardjowigeno (2007) mengatakan unsur nitrogen sangat dibutuhkan tanaman pada awal

Tabel 3. Pertumbuhan tanaman pepaya pada perlakuan konsentrasi suspensi PGPR dan komposisi media tanam di polybag

\begin{tabular}{|c|c|c|c|c|c|}
\hline Perlakuan & Tinggi tanaman $(\mathrm{cm})$ & Jumlah Daun (helai) & $\begin{array}{l}\text { Diameter batang } \\
(\mathrm{mm})\end{array}$ & Panjang daun & $\begin{array}{c}\text { Lebar } \\
\text { daun }\end{array}$ \\
\hline PGPR & \multicolumn{5}{|c|}{$1 \mathrm{MST}$} \\
\hline $0 \mathrm{ml} / 1$ & $5,48 \mathrm{c}$ & $2,00 \mathrm{a}$ & $0,60 \mathrm{c}$ & $2,01 b$ & $3,48 \mathrm{ab}$ \\
\hline $5 \mathrm{ml} / \mathrm{l}$ & $6,10 b$ & $2,00 \mathrm{a}$ & $1,40 b$ & $2,11 \mathrm{ab}$ & $3,80 \mathrm{a}$ \\
\hline $10 \mathrm{ml} / \mathrm{l}$ & $6,34 b$ & $2,00 \mathrm{a}$ & $1,54 \mathrm{ab}$ & $2,14 \mathrm{ab}$ & $3,31 b$ \\
\hline $15 \mathrm{ml} / \mathrm{l}$ & $7,12 \mathrm{a}$ & $2,00 \mathrm{a}$ & $1,71 \mathrm{a}$ & $2,41 \mathrm{a}$ & $3,46 a$ \\
\hline \multicolumn{6}{|l|}{ Media } \\
\hline M0 & $6,42 b$ & $2,00 \mathrm{a}$ & $1,26 \mathrm{a}$ & $2,34 \mathrm{a}$ & $3,56 a$ \\
\hline M1 & $6,39 a$ & $2,00 \mathrm{a}$ & $1,46 a$ & $2,09 \mathrm{ab}$ & $3,61 \mathrm{a}$ \\
\hline M2 & $5,97 \mathrm{a}$ & $2,00 \mathrm{a}$ & $1,22 \mathrm{a}$ & $2,07 \mathrm{~b}$ & $3,37 \mathrm{a}$ \\
\hline PGPR & \multicolumn{5}{|c|}{$4 \mathrm{MST}$} \\
\hline $0 \mathrm{ml} / \mathrm{l}$ & $9,69 b$ & $6,63 a b$ & $2,46 b$ & $3,41 b$ & 4,75 \\
\hline $5 \mathrm{ml} / \mathrm{l}$ & $10,17 b$ & $6,25 b$ & $3,10 \mathrm{a}$ & $3,63 \mathrm{ab}$ & 5,33 \\
\hline $10 \mathrm{ml} / \mathrm{l}$ & $10,54 b$ & $6,66 a$ & $3,17 \mathrm{a}$ & $3,54 \mathrm{ab}$ & 5,09 \\
\hline $15 \mathrm{ml} / \mathrm{l}$ & $12,00 \mathrm{a}$ & $6,48 \mathrm{ab}$ & $3,17 \mathrm{a}$ & $3,93 \mathrm{a}$ & 5,27 \\
\hline \multicolumn{6}{|l|}{ Media } \\
\hline M0 & 11,01 & $6,41 \mathrm{a}$ & 2,91ab & $3,59 \mathrm{a}$ & 5,38 \\
\hline M1 & 10,94 & $6,52 \mathrm{a}$ & $3,26 a$ & $3,80 \mathrm{a}$ & 5,22 \\
\hline M2 & 9,85 & $6,58 \mathrm{a}$ & $2,76 \mathrm{~b}$ & $3,48 \mathrm{a}$ & 4,78 \\
\hline
\end{tabular}

Keterangan : Angka yang diikuti huruf berbeda pada kolom yang sama menunjukkan berbeda nyata berdasarkan hasi uji lanjut Duncan Multiple Range Test (DMRT) $\alpha=5 \%$, 0: K0, 5: K1, 10: K2, 15: K3, Tanah: pupuk kandang (M0), tanah: pupuk kandang: sekam (M1), tanah: pupuk kandang: cocopeat (M2).

\section{Pertumbuhan Tanaman Pepaya di Lapangan}

Pertumbuhan tanaman pepaya pada perlakuan perendaman PGPR berpengaruh terhadap pertumbuhan tinggi, jumlah daun, panjang daun dan lebar daun tanaman pepaya. Perlakuan yang paling berpengaruh diperoleh pada perlakuan K3, nilai tertinggi untuk tinggi tanaman sebesar 72,51 cm, jumlah daun 25,87 helai, panjang daun sebesar $42,39 \mathrm{~cm}$ dan lebar daun sebesar 39,65 cm (Tabel 4). Berbeda dengan peubah sebelumnya untuk jumlah daun nilai tertinggi diperoleh pada perlakuan K1 sebesar 25,87 helai. Menurut Irianti (2010) jumlah daun tanaman pepaya terutama pada fase vegetatif sangat berpengaruh pada kecepatan tumbuh tanaman dan perkembangan organ lain pada tanaman. Perlakuan konsentrasi suspensi PGPR yang diharapkan adalah PGPR dapat memberikan pertumbuhan atau fase vegetatif. Menurut Sujiprihati dan Suketi (2009) Tujuan dari pembibitan adalah untuk mendapatkan bibit pepaya yang sehat, tumbuh secara optimal, dan mempunyai daya adaptasi yang baik saat dipindahkan ke lapangan. Menurut Zulkarnain (2009) kriteria bibit yang berkualitas baik yaitu bibit sehat dan bebas dari investasi patogen, benih yang digunakan berasal dari tanaman induk yang berpotensi hasil tinggi. 
tanaman asal bibit dari komposisi media tanam tanah, pupuk kandang dan cocopeat $(57,98 \mathrm{~cm})$. Tanaman dari asal bibit yang ditanam pada komposisi media tanah dan pupuk kandang (M0) berbeda dengan media tanah, pupuk kandang dan cocopeat (M2) tetapi tidak berbeda dengan komposisi media tanah, pupuk kandang dan sekam (M1). Nakasone dan Paull (1999) pertumbuhan batang pepaya sangat cepat sampai tanaman mulai berbunga dengan laju pertumbuhan mencapai 2 mm per hari. Menurut Azhari (2006) pola tumbuh suatu tanaman mengikuti kurva sigmoid yang terdiri atas beberapa fase yaitu fase tumbuh lambat (kecambah), fase tumbuh exponensial (cepat), fase tumbuh linier (cepat), fase tumbuh lambat dan fase tumbuh stabil.

Perlakuan komposisi media tanam juga mempengaruhi jumlah daun tanaman pepaya di lapangan. Dengan media tanam tanah, pupuk kandang dan cocopeat memiliki nilai dengan jumlah tertinggi yaitu 25,50 helai tetapi tidak berbeda dengan komposisi media tanah, pupuk kandang dan sekam. Sedangkan jumlah daun tanaman dari bibit yang ditanam pada komposisi media tanam tanah dan pupuk kandang berbeda dengan yang lainnya. Hasil ini berbeda dengan penelitian Dewi dan Suketi (2004) yang menunjukkan bahwa perlakuan terbaik media tanam campuran tanah, arang sekam, dan pupuk kandang dengan perbandingan 2:1:1 memberikan pertambahan tinggi tanaman, jumlah daun, diameter batang, panjang tunas, dan volume akar yang lebih besar pada bibit mangga. Menurut Gardner et al. (1991) faktor-faktor yang mempengaruhi pertumbuhan dapat dikategorikan sebagai faktor eksternal (lingkungan) dan internal (genetik).

Tabel 4. Pertumbuhan tanaman pepaya pada perlakuan konsentrasi suspensi PGPR dan komposisi media tanam 13 MST di lapangan

\begin{tabular}{llrrcc}
\hline Perlakuan & $\begin{array}{c}\text { Tinggi tanaman } \\
(\mathrm{cm})\end{array}$ & Jumlah Daun (helai) & $\begin{array}{c}\text { Diameter batang } \\
(\mathrm{mm})\end{array}$ & $\begin{array}{c}\text { Panjang daun } \\
(\mathrm{cm})\end{array}$ & $\begin{array}{c}\text { Lebar daun } \\
(\mathrm{cm})\end{array}$ \\
\hline PGPR & & & & & \\
$0 \mathrm{ml} / \mathrm{L}$ & $60,62 \mathrm{~b}$ & $25,53 \mathrm{a}$ & 38,89 & $38,01 \mathrm{~b}$ & $37,12 \mathrm{ab}$ \\
$5 \mathrm{ml} / \mathrm{L}$ & $56,76 \mathrm{~b}$ & $25,87 \mathrm{a}$ & 38,64 & $39,27 \mathrm{~b}$ & $36,20 \mathrm{~b}$ \\
$10 \mathrm{ml} / \mathrm{L}$ & $61,08 \mathrm{~b}$ & $24,37 \mathrm{~b}$ & 38,13 & $39,25 \mathrm{~b}$ & $37,70 \mathrm{ab}$ \\
$15 \mathrm{ml} / \mathrm{L}$ & $72,51 \mathrm{a}$ & $25,00 \mathrm{ab}$ & 38,47 & $42,39 \mathrm{a}$ & $39,65 \mathrm{a}$ \\
Media & & & & & \\
M0 & $68,79 \mathrm{a}$ & $24,65 \mathrm{~b}$ & 39,68 & 40,67 & 37,64 \\
M1 & $61,47 \mathrm{ab}$ & $25,43 \mathrm{a}$ & 38,33 & 39,31 & 37,90 \\
M2 & $57,98 \mathrm{~b}$ & $25,50 \mathrm{a}$ & 37,58 & 39,21 & 37,47 \\
\hline
\end{tabular}

Keterangan : Angka yang diikuti huruf berbeda pada kolom yang sama menunjukkan berbeda nyata berdasarkan hasil uji lanjut Duncan Multiple Range Test (DMRT) $\alpha=5 \%$, 0: K0, 5: K1, 10: K2, 15: K3, Tanah: pupuk kandang (M0), tanah: pupuk kandang: sekam (M1), tanah: pupuk kandang: cocopeat (M2).

\section{Fase Generatif}

Penelitian ini pengamatan yang dilakukan yaitu waktu bunga pertama muncul dan jumlah bunga pada tanaman pepaya. Konsentrasi suspensi PGPR dan komposisi media tanam tidak berpengaruh terhadap waktu bunga pertama muncul dan jumlah bunga (Tabel 5). Hal ini mungkin disebabkan waktu penanaman di lapangan memasuki musim hujan dan pada saat waktu penyiraman, hujan terlalu cepat turun sehingga larutan semakin cepat tercuci oleh air hujan. Taufik (2010) menyatakan bahwa aplikasi PGPR pada benih cabai mampu meningkatkan pertumbuhan generatif tanaman cabai. Hal ini berbeda dengan hasil penelitian Imanda (2012) bahwa media tanam tanah, pupuk kandang dan arang sekam memiliki waktu bunga muncul lebih cepat.

Saryoko (2004) dalam penelitiannya menyatakan bahwa munculnya bunga pertama pada tanaman pepaya dapat dipengaruhi oleh kondisi lingkungan dan genetiknya. Menurut Sujiprihati dan Suketi (2009) bunga pepaya pertama muncul pada saat tanaman berumur 3-4 bulan. Hasil penelitian Suketi (2011) menunjukkan bahwa waktu bunga pertama muncul dari genotipe pepaya IPB 3, IPB 9 dan IPB 9 x IPB 3 yaitu pada 15.33 MST sedangkan pepaya IPB 1 pada 18 MST. 
Tabel 5. Waktu bunga pertama muncul dan jumlah bunga yang muncul pada tanaman pepaya di lapangan

\begin{tabular}{lcc}
\hline Perlakuan & Waktu bunga pertama muncul (hari) & Jumlah bunga yang muncul \\
\hline PGPR & & \\
$0 \mathrm{ml} / \mathrm{L}$ & 57,51 & 10,96 \\
$5 \mathrm{ml} / \mathrm{L}$ & 56,77 & 12,03 \\
$10 \mathrm{ml} / \mathrm{L}$ & 56,77 & 11,07 \\
$15 \mathrm{ml} / \mathrm{L}$ & 56,77 & 12,29 \\
Media & & \\
M0 & 56,58 & 11,58 \\
M1 & 56,94 & 11,47 \\
M2 & 57,36 & 11,72 \\
\hline
\end{tabular}

Keterangan : Angka yang diikuti huruf berbeda pada kolom yang sama menunjukkan berbeda nyata berdasarkan hasil uji lanjut Duncan Multiple Range Test (DMRT) $\alpha=5 \%$, 0: K0, 5: K1, 10: K2, 15: K3, Tanah: pupuk kandang (M0), tanah: pupuk kandang: sekam (M1), tanah: pupuk kandang: cocopeat (M2).

\section{KESIMPULAN}

PGPR mempengaruhi tinggi tanaman, diameter batang dan panjang daun pada saat penanaman di polybag. Tinggi tanaman dan panjang daun tertinggi pada saat di lapangan diperoleh konsentrasi PGPR dengan perlakuan 15 $\mathrm{ml} / \mathrm{l} 60$ menit (K3). Sedangkan pada perlakuan media tanam tanah dan pupuk kandang (M0) dan tanah, pupuk kandang dan sekam (M1) merupakan media paling baik untuk bibit pepaya. Kombinasi konsentrasi suspensi PGPR dan komposisi media tanam terbaik adalah $15 \mathrm{ml} / \mathrm{l}$ dengan komposisi media tanam tanah dan pupuk kandang (K3M0).

\section{DAFTAR PUSTAKA}

Azhari, S. 2006. Hortikultura Aspek Budidaya. Jakarta (ID) : UI Press.

Beets, W.C. 1982. Multiple Cropping and Tropical Farming Systems. Publ. Gower, Inggris.

[BPS] Badan Pusat Statistik. 2015. Tabel produksi tanaman pepaya provinsi Indonesia. [Internet] [diunduh 2015 Desember 20] Tersedia pada http://www.bps.go.id

[BPTBT] Balai Pengkajian Tanaman Buah Tropika. 2008. Pengelolaan kebun pepaya sehat. Balai Pengkajian Tanaman Buah Tropika, Solok.

Chaeningrum, R. 2010. Analisis usahatani pepaya California (kasus : Desa Cikopo Mayak, Kecamatan Jasinga, Kabupaten Bogor, Provinsi Jawa Barat). [Skripsi]. Institut Pertanian Bogor. Bogor.
Dewi, K. dan K. Suketi. 2004. Respon pertumbuhan bibit stum mangga (Mangifera indica L.) varietas Kelapa Arum dan Arum Manis pada komposisi media dan ukuran wadah berbeda. Dalam: Efendi D., Surahman M., Hadad M., Suhartanto M.R, Sujiprihati S., Subandriyo, dan Trikoesoemaningtyas, $(E d s)$. Simposium Perhimpunan Ilmu Pemuliaan Indonesia; Menuju Indonesia Berswasembada Varietas Unggul. Bogor, 5- 7 Agustus 2004.

Dita, R.S. 2014. Pengaruh konsentrasi dan lama perendaman plant growth promoting rhizobacteria (PGPR) pada pertumbuhan tanaman seledri (Apium graveolens L.). [Skripsi]. Fakultas Pertanian Universitas Pekalongan. Pekalongan.

Gardner, F.P., R.B. Pearce dan R.L. Mitchell. 1991. Fisiologi Tanaman Budidaya. Jakarta (ID): Universitas Indonesia Press.

Hardjowigeno, S. 2007. Ilmu Tanah. Jakarta (ID): Akademika Presindo.

Irianti, F. 2010. Pengaruh aplikasi pemupukan melalui lubang resapan biopori terhadap vigor bibit tanaman pepaya (Carica papaya L.). [Skripsi]. Institut Pertanian Bogor. Bogor.

Kalie, M.B. 1999. Bertanam Pepaya. Jakarta (ID): Penebar Swadaya.

Nakasone, H.Y. and R.E. Paull. 1998. Tropical Fruits. Wallingford (USA): $\mathrm{CAB}$ International. 
Nakasone, H.Y. and R.E. Paull. 1999. Crop Production Science in Horticulture. Wallingford (ID): CAB International.

Nasib, S.B. 2015. Pengaruh plant growth promoting rhizobacteria terhadap bibit dan pertumbuhan awal pepaya di lapang. [Skripsi]. Institut Pertanian Bogor. Bogor.

Nugrahani, N.L. 2015. Pengaruh komposisi media taman terhadap bibit dan pertumbuhan awal pepaya (Carica papaya L.) tipe bangkok dan california. [Skripsi]. Institut Pertanian Bogor. Bogor.

[PKHT] Pusat Kajian Hortikultura Tropika. 2009. Pengembangan Benih Unggulan. LPPM IPB, Bogor. Saryoko A. 2004. Karakterisasi Morfologi dan Evaluasi Daya Hasil 20 Genotipe Pepaya. [Skripsi]. Institut Pertanian Bogor. Bogor.

Sobir. 2009. Budidaya Tanaman Buah Unggul Indonesia. Jakarta (ID): Agromedia Pustaka.

Sujiprihati, S. dan K Suketi. 2009. Budi Daya Pepaya Unggul. Jakarta (ID): Penebar Swadaya.

Suketi, K. 2011. Studi morfologi bunga, penyerbukan dan perkembangan buah sebagai dasar pengendalian mutu buah pepaya IPB. [Disertasi]. Sekolah
Pascasarjana. Institut Pertanian Bogor. Bogor.

Suketi, K., R. Poerwanto, S. Sujiprihati, Sobir dan W.D. Widodo. 2010. Studi karakter mutu buah pepaya IPB. J. Hort. Indonesia 1(1):17-26.

Suyanti. 2011. Peranan teknologi pascapanen untuk meningkatkan mutu buah pepaya (Carica papaya L.). Buletin Teknologi Pascapanen Pertanian 7(2):96-103.

Tanuta, M. 2006. Plant growth promoting rhizobacteria: Prospect for increasing nutrient acquisition and disease control. [Internet] [diunduh pada 2016 Februari 24] Tersedia pada http://www.umanitoba.ca.

Utami, R.D., W.D. Widodo dan K. Suketi. 2013. Pertumbuhan bibit pepaya pada berbagai komposisi media tanam. Dalam J.G. Kartika., W.B. Suwarno., S.W. Ardhi., C.P.E. Sanura. dan F.N. Fitriana $(E d s)$. Prosiding Seminar Ilmiah PERHORTI. Membangun Sistem Baru Agribisnis Hortikultura Indonesia pada Era Pasar Global. Bogor, 9 Oktober 2013.

Zulkarnain. 2009. Dasar-dasar Hortikultura. Jakarta (ID): PT Bumi Aksara. 